\title{
Entomopathogens as biological control of the mediterranean flour moth, Ephestia kuehniella (Lepidoptera: Pyralidae)
}

\author{
Akdeniz un güvesi Ephestia kuehniella (Lepidoptera: Pyralidae)'nın biyolojik kontrolünde entomopatojenler
}

\author{
Mustafa YAMAN $^{1}(\mathbb{D})$, Tuğba SAĞLAM ${ }^{1}$ (D) Ömer ERTÜRK ${ }^{2}$ (D) \\ ${ }^{1}$ Department of Biology, Faculty of Arts and Science, Bolu Abant izzet Baysal University, 14030, Bolu, Turkey. \\ 2 Department of Molecular Biology and Genetics, Faculty of Arts and Sciences, Ordu University, 52750 Ordu, Turkey.
}

Eser Bilgisi / Article Info

Derleme makale / Review article

DOI: 10.17474/artvinofd.918426

Sorumlu yazar / Corresponding author

Ömer ERTÜRK

e-mail: oseerturk@hotmail.com

\section{Geliş tarihi / Received}

16.04.2021

Düzeltme tarihi / Received in revised form

12.09.2021

Kabul Tarihi / Accepted

22.09.2021

Elektronik erişim / Online available

18.11.2021

Keywords:

Biological control

Entomopathogen

Ephestia kuehniella

Lepidoptera

Anahtar kelimeler:

Biyolojik kontrol

Entomopatojen

Ephestia kuehniella

Lepidoptera

\begin{abstract}
Mediterranean flour moth Ephestia kuehniella (Zeller, Lepidoptera: Pyralidae) is one of the most important insect pests that invade the stored grain of many grains around the world. Chemical control is a very preferred method in the fight of this pest. However, due to the economic, social and environmental damages of chemicals, the interest in biological control, which is an alternative method, is gradually increasing. Entomopathogens have very important in biological control and that cause desired infections in pests. Entomopathogens include many species such as viruses, bacteria, protists, fungi and nematodes. In recent years, entomopathogeic nematodes; Steinernema feltiae, Steinernema carpocapsae, Steinernema riobrave, Heterorhabditis bacteriophora, Heterorhabditis sp., Steinernema sp., and Xenorhabdus nematophila, entomopathogenic fungi; Paecilomyces fumosoroseus (=Isaria fumosorosea), Beuveria bassiana and Metarhizium anisopliae, entomopathogenic bacteria; Bacillus thuringiensis subsp. kurstaki, Photorhabdus temperata and Bacillus subtilis, entomopathogenic protists; Vairimorpha ephestiae, Leidyana ephestiae, Mattesia dispora and Mattesia oryzaephili, and virus; Nuclear Polyhedrosis Virus (NPV) were reported from E.kuehniella. In this review, it is aimed to evaluate the recent status of these entomopathogenic organisms found or tested for $E$. kuehniella.
\end{abstract}

\begin{abstract}
Özet
Akdeniz un güvesi Ephestia kuehniella (Zeller, Lepidoptera: Pyralidae), dünyada birçok depolanmış tahılı istila eden en önemli böcek zararlılarından biridir. Zararlıyla mücadelede kimyasal mücadele çok tercih edilen bir yöntemdir. Bununla birlikte, kimyasalların ekonomik, sosyal ve çevresel zararlarından dolayı, alternatif bir yöntem olan biyolojik kontrole olan ilgi giderek artmaktadır. Entomopatojenler biyolojik kontrolde çok önemlidir ve zararlılarda istenen enfeksiyonlara neden olurlar. Entomopatojenlerin virüsler, bakteriler, protistler, mantarlar ve nematodlar gibi birçok türü vardır. Son yıllarda, entomopatojenik nematodlar; Steinernema feltiae, Steinernema carpocapsae, Steinernema riobrave, Heterorhabditis bacteriophora, Heterorhabditis sp., Steinernema sp. ve Xenorhabdus nematophila, entomopatojenik mantarlar; Paecilomyces fumosoroseus (=Isaria fumosorosea), Beuveria bassiana, Metarhizium anisopliae, entomopatojenik bakteriler; Bacillus thuringiensis subsp. kurstaki, Photorhabdus temperata, Bacillus thuringiensis ve Bacillus subtilis, entomopatojenik protistler; Vairimorpha ephestiae, Leidyana ephestiae, Mattesia dispora ve Mattesia oryzaephili ve son olarak Nükleer Polihedrozis Virüs (NPV) E. kuehniella'da bulunmuş yada ona karşı test edilmiştir. Bu derlemede, $E$. kuehniella popülasyonlarında bulunan veya test edilen bu entomopatojenik organizmaların değerlendirilmesi amaçlanmıştır.
\end{abstract}

\section{INTRODUCTION}

Lepidoptera, known as stored product pests, feeds on foods like grain. They increase the temperature and humidity in the grain during feeding, and also contaminate the products with the remains of feces and body parts (Ramos-Rodríguez et al. 2006, Barbosa Negrisoli et al. 2013). The European flour moth (Ephestia kuehniella (Zeller)) is known as a common warehouse pest in mills, feed mills and food. The adults usually live 23 weeks. Females lay about 150-200 (or even more) eggs on crops. The larvae emerging from the eggs quickly feed and cause the damage. The pest raises 5-6 annual generations. E. kuehniella larvae of this trust both cause direct damage through nutrition and their presence on food also reduces product quality (Jallouli et al. 2013). E. kuehniella is known as first degree in flour and second degree harmful in cereals (Paula Pereira et al. 2002). E. kuehniella larvae not only cause direct damage by feeding, but also decrease the product quality with their presence in the product and the net they weave (Jallouli et al. 2013).

Pest control methods are known as natural control, legal control, mechanical control, physical control, cultural control, biological control, chemical control and 
integrated control. One of the most commonly used methods in Lepidopteran species (such as E. kuehniella) is fumigation. Fumigation is a chemical control method. But, chemicals have extremely serious negative effects on the environment and human health. The use of chemical compounds has negative effects on non-target organisms (Arıkan and Turan 2020).Due to the side effects of chemicals, this control method should be limited. Therefore, in recent years, alternative methods have been investigated against the use of chemicals in many countries due to their negative effects on both human health and the ozone layer (Freitas et al. 2020). The most remarkable of these alternative methods is the method of struggle with the use of entomopathogens. The UK government had designed a project to control pests in stored foods. In this project, instead of organophosphate, pesticide and methyl bromide, use of entomopathogenic fungi was investigated. As a result of this project, it has been observed that some isolates obtained from Beauveria bassiana cause $100 \%$ death in some pest species within 7 days (Cox et al. 2002). Among the important hidden pests encountered in stored products, E. kuehniella is a very common pest (Stejskal et al. 2020). In this context, there are many publications and studies on entomopathogens detected from E. kuehniella. According to the available literature, entomopathogens detected from E. kuehniella are viruses, bacteria, protists, fungi and nematodes.

\section{Entomopathogens tested against or isolated from $E$. kuehniella for biological control}

\section{Viruses}

Entomopathogenic viruses are significant agents of biological control due to features such as non-toxicity to vertebrates and eco-friendliness (Clem and Passarelli 2013). Among the viruses, baculoviruses have very important due to their entomopathogenicity (Hails 2001, Karabörklü et al. 2018). There are many baculovirus origin products that are commercially produced for this purpose (Clem and Passarelli 2013). According to literatures, a list including entomopathogenic viruses of E.kuehniella populations and are as agents for natural control of this is given in the Table 1.

Lynn et al. (2004) performed nucleopolyhedrovirus inoculation to E. kuehniella cultures. Most grafted $E$. kuehniella cultures have been found to be highly susceptible to nucleopolyhedrovirus. Researchers think that their results may be useful in biocontrol research.

Table 1. Entomopathogenic viruses found or tested for E. kuehniella.

\begin{tabular}{ccc}
\hline Entomopathogen Group & Entomopathogen Species & References \\
\hline Viruses & Nucleopolyhedrovirus (NPV) & Lynn and Ferkovich (2004), Yaman et al. (2015). \\
\hline
\end{tabular}

Yaman et al. (2015) isolated a Nucleopolyhedrovirus (NPV) from laboratory-supported larvae of E. kuehniella. Under the light microscope, a large number of polyhedral inclusion bodies (PIBs) were observed in hemolymph, trachea and midgut. In addition, some diamond shaped inclusion bodies, such as virion-free spindles, were also observed in this study. Researchers reported that Nucleopolyhedrovirus (NPV) was first time isolated and characterized from $E$. kuehniella.

\section{Bacteria}

Entomopathogenic bacteria cause mass death in insects. These organisms enter the host through digestion and produce toxins and other pathogenic factors that disrupt the midgut epithelium, thereby causing septicemia and death of the insect host. Bacillus thuringiensis (Bt) (Berliner) is common in soil, is a deadly pathogen of many pests and is the most widely used entomopathogenic biological control agent (JuratFuentes and Jackson 2012). There are currently more than $40 \mathrm{Bt}$ products available for the control of insect pests, which make up $1 \%$ of the global pesticide market. Especially, these bacterial preparations are used against Lepidopteran species (Krieg et al. 1983, Jamoussi et al. 2009). According to this information and the literature data obtained, a list containing the entomopathogenic bacteria of $E$. kuehniella populations and agents for their natural control is given in Table 2 .

Mostafa et al. (2005) tested B. thuringiensis var. kurstaki against $E$. kuehniella fifth instar larvae. In the study, it was observed survival time shortened in the larvae fed with bacterial preparation.

Mahbubur Rahman et al. (2007) investigated the effects of $B$. thuringiensis-toxin formulation against the defense systems of E. kuehniella larvae. In the study was observed 
that melanization significantly reduced in hemolymphes of larvae infected with $B$. thuringiensis-toxin. Researchers say that hemolymph melanization is associated with a high immune status.

Jamoussi et al. (2009) tested Photorhabdus temperata (Fischer-Le Saux et al.) and B. thuringiensis bacteria against $E$. kuehniella larvae. In this study, it was studied the first time effectiveness of the $P$. temperata vip3LB gene. Result of the study, it has been determined that recombinant bacteria expressing the vip3LB gene reduce or stop larval growth. Also, this study showed that vip3LB gene may increase the insecticidal activities of $B$. thuringiensis and $P$. temperata.

Ghribi et al. (2012) determined E. kuehniella larvicidal power of biosurfactant secreted by Bacillus subtilis (Ehrenberg). In the study, the biosurfactant tested against third instar larvae of $E$. kuehniella. Researhers found that biosurfactants can be resistant to environmental stresses such as extreme $\mathrm{pH}$, temperature and sunlight / UV radiation. According to researchers, thanks to these features of the biosurfactant secreted by $B$. subtilis, it can be used against $E$. kuehniella larvae.

BenFarhat et al. (2013) investigated the effect of $B$. thuringiensis and Xenorhabdus nematophila (Poinar and Thomas) cells on the growth of $E$. kuehniella larvae. In the study, mixture of $X$. nematophila and $B$. thuringiensis had negative effects on the growth of $E$. kuehniella larvae.

Jallouli et al. (2013) conducted research on the insecticidal activity of the entomopathogenic bacterium $P$. temperata against $E$. kuehniella. Larvae fed on with $P$. temperata culture did not appear adult form. In the treatment with a high concentration of $P$. temperata culture, E. kuehniella larvae was mortality rate $100 \%$.

Table 2. Entomopathogenic bacteria found or tested for E. kuehniella.

\begin{tabular}{ccc}
\hline Entomopathogen Group & Entomopathogen Species & References \\
\hline \multirow{2}{*}{ Bacteria } & Bacillus thuringiensis & Mostafa et al. (2005), Mahbubur Rahman et al. (2007), Jamoussi et al. (2009) \\
& Bacillus subtilis & Ghribi et al. (2012), \\
& Bacillus thuringiensis subsp. kurstaki & BenFarhat et al. (2013) \\
& Xenorhabdus nematophila & BenFarhat et al. (2013) \\
& Photorhabdus temperata & Jallouli et al. (2013) \\
\hline
\end{tabular}

\section{Protists}

Several groups of protists cause disease in insects and are of interest as agents for natural control of insect pests (Yaman 2020). These organisms are known as entomopathogenic protists. The most important entomopathogenic species belong to Microspora (Microsporidians), Sarcomastigophora (Flagellates and Rhizopods) and Apicomplexa (Gregarines and Coccidian). Microsporidian pathogens often cause the host (insect) to die (Yaman et al. 2019). Sometimes it reduces the nutritional abilities of the host by restricting its vital activities (Andreadis 1985, Didier 2005, Yaman 2010). For example, gregarine infection reduces the resistance of insects, negatively affects their development and reproduction. Thus, insects that are not resistant to adverse environmental conditions die more easily than healthy insects (Dales 1994, Lipa and Triggiani 1992, Valigurová and Koudela 2006). According to this information and the literature data obtained, a list containing the entomopathogenic protist (microsporidia and gregarine) of $E$.kuehniella populations and agents for their natural control is given in Table 3.
Weiser and Purrini (1985) documented the ultrastructure of the Vairimorpha ephestiae (Mattes) (Protozoa, Microsporidia) from E. kuehniella larvae. According to researchers, development of $V$. ephestiae are two types of sporogony; one ending with single binucleate spores, and a second with spores in octosporous pansporoblasts. These spores are uninucleate. Elongate oval spores of two sizes differ in number of nuclei. They have a long polar filament deposed in 14 coils in one layer beneath the spore wall.

Lord (2003) tested the mortality doses of Mattesia oryzaephili and Mattesia dispora against E. kuehniella. Doses of $M$. oryzaephili and $M$. dispora were given as a diet for E. kuehniella. At the end of the study, they determined the median lethal doses as $7.9 \times 10^{7}$ oocysts $/ g$ of diet for $M$. oryzaephili and $2.7 \times 10^{3} \mathrm{M}$. dispora on $E$. kuehniella.

Valigurová and Koudela (2005) described the structure of the Leidyana ephestiae from E. kuehniella larvae. The intestines of young and mature trophozoites of experimentally infected E. kuehniella larvae were examined by electron microscopy. Young trophozoites 
were small, oval to ovoid, and possessed a simple, globular epimerite. Mature trophozoites have shown a large oval epimerite with many mitochondria and vesicles.

Valigurová and Koudela (2006) described the structure of the M. dispora, from E. kuehniella larvae.
Yaman et al. (2019) identified a neogregarine pathogen, Mattesia dispora from E. kuehniella from Turkey for the first time. In addition, they also documented the occurrence of the pathogen in different life stages of $E$. kuehniella. The pathogen was determined cause different infection levels in the larvae, pupae and adults of $E$. kuehniella, 57.06, 85 and $3.17 \%$ respectively.

Table 3. Entomopathogenic protists found or tested for E. kuehniella.

\begin{tabular}{ccc}
\hline Entomopathogen Group & Entomopathogen Species & References \\
\hline Microsporidia & Vairimorpha ephestiae & Weiser and Purrini (1985) \\
Gregarines & Mattesia dispora & Lord (2003), Valigurová and Koudela (2006), Yaman et al. (2019) \\
& Mattesia oryzaephili & Lord (2003) \\
& Leidyana ephestiae & Valigurová and Koudela (2005) \\
\hline
\end{tabular}

\section{Fungi}

Entomopathogenic fungi (EPF) form spore resistant to adverse environmental conditions, also have saprophytic life cycles. Entomopathogenic fungi do not have a toxic effect on mammals (Vega et al. 2012). They do not form resistant to insects. It infects the different stages of the host and the environment for a long time. With these features, they have an important place in biological control (Erkılıç and Uygun 1993). For this reason, there are many commercially available fungal preparations (Vega et al. 2012). And these preparations are successfully used to combat pests. However, it has disadvantages such as slow killing, high humidity, inability to be used with fungicides, expensive production and storage difficulty (Goettel et al. 2005, Sevim et al. 2015). According to literatures, a list including the entomopathogenic fungi of $E$. kuehniella as agents for natural control of this pest is given in the Table 4 .

Wildey et al. (2002) conducted a study on the use of entomopathogenic fungi for pest control in stored products. In the laboratory, researchers tested fungal samples against insects, moths (E. kuehniella) and mites. They found that Beauveria bassiana strains performed better than other entomopathogenic fungi against $E$. kuehniella. Researchers stated that B. bassiana may be an alternative biocontrol agent to pesticides.

Michalaki et al. (2007) investigated the insecticidal effect of entomopathogenic fungus Paecilomyces fumosoroseus. This EPF Paecilomyces fumosoroseus, was applied to the wheat in the storages in doses. As a result, researchers found that the mortality of $E$. kuehniella larvae did not exceed $56 \%$.
Abdalla et al. (2012) studied natural entomopathogenic agents against $E$. kuehniella. As a result of study, $E$. kuehniella larvae was found to sensitive to $B$. bassiana, Metarhizium anisopliae and Verticillium lecanii.

Mahmoud Sabbour et al. (2012) tested Beauveria bassiana, Metarhizium anisopliae and Isaria fumosorosea against E. kuehniella. As a result of the study, it was observed that $E$. kuehniella was very sensitive to $M$. anisopliae and $B$. bassiana. In addition, B. bassiana has been found to be the most effective fungus species against E. kuehniella.

Faraji et al. (2013) tested entomopathogenic fungi, Beauveria bassiana and Metarhizium anisopliae against the third instar larvae of E. kuehniella. The results showed that entomopathogenic fungi can be used as an alternative method to pest control in Insect Pest Management (IPM) programs.

Rahimi et al. (2013) tested the mixtures of pyriproxyfen and hexaflumuron, known as insect growth regulators with $B$. bassiana against $E$. kuehniella. The results of the study showed pyriproxyfen and hexaflumuron are selective and safe for non-target organisms. In addition, it has been found combination of pyriproxyfen and hexaflumuron with $B$. bassiana may be more effective against E. kuehniella.

Sabbour (2013) tested the different concentrations of $M$. anisopliae toxin, destruxin and nano-destruxin against $E$. kuehniella under laboratory and store conditions. Different concentrations of fungi toxin, destruxin and nano-destruxin were applied in the study. As a result of the study, it was determined the number of eggs decrease of E. kuehniella. 
Shakarami et al. (2015) tested entomopathogenic fungus B. bassiana and three different botanical compounds against the third instar larvae of E. kuehniella. They conducted experiments under suitable laboratory conditions and suitable photoperiod. Results showed that all botanical compounds and entomopathogenic fungi exhibited larvicidal activity against E. kuehniella. In addition, it showed that $B$. bassiana and essential oil mixture had a synergistic effect on the mortality of $E$. kuehniella larvae.

Jarrahi and Safavi (2016) treated E. kuehniella larvae with $M$. anisopliae. Then, researchers examined the behavior performance in Habrobracon hebetor. In that study, they determined that it is appropriate to use $M$. anisopliae and $H$. hebetor together for biological control of E. kuehniella.
Athanassiou et al. (2017) tested the insecticidal activity of $M$. anisopliae against E. kuehniella larvae. In the study, the death of $E$. kuehniella larvae was observed between $41.1 \%$ and $93.3 \%$. In addition, increase in temperature was found to be an important factor for $M$. anisopliae performance.

Seyedtalebi et al. (2017) tested five different B. bassiana isolates against $E$. kuehniella. Also, they evaluated the defense reactions of $E$. kuehniella against $B$. bassiana. In the results of working, researchers observed $E$. kuehniella was moderately sensitive to $B$. bassiana. The research provides an interesting perspective on the susceptibility of pests to fungal infections.

Table 4. Entomopathogenic fungi found or tested for E. kuehniella.

\begin{tabular}{|c|c|c|}
\hline $\begin{array}{l}\text { Entomopathogen } \\
\text { Group }\end{array}$ & Entomopathogen Species & References \\
\hline \multirow{4}{*}{ Fungi } & Beuveria bassiana & $\begin{array}{l}\text { Wildey et al. (2002), Abdalla et al. (2012), Mahmoud Sabbour et al. (2012), Faraji et } \\
\text { al. (2013), Rahimi et al. (2013), Shakarami et al. (2015), Seyedtalebi et al. (2017) }\end{array}$ \\
\hline & Metarhizium anisopliae & $\begin{array}{l}\text { Abdalla et al. (2012), Mahmoud Sabbour et al. (2012), Faraji et al. (2013), Sabbour } \\
\text { (2013), Jarrahi and Safavi (2016), Athanassiou et al. (2017) }\end{array}$ \\
\hline & $\begin{array}{l}\text { Paecilomyces fumosoroseus } \\
\text { (=Isaria fumosorosea) }\end{array}$ & Michalaki et al. (2007), Mahmoud Sabbour et al. (2012) \\
\hline & Verticillium lecanii & Abdalla et al. (2012) \\
\hline
\end{tabular}

\section{Nematode}

Some entomopathogenic nematodes in the family Steinernematidae and Heterorhabditidae are used as effective biocontrol agents against many pests. These nematode types can also play an important role in Insect Pest Management (IPM) (Wouts 1991, Tulek et al. 2015). Because, they are considered non-toxic to humans, relatively specific to their target pests, and can be applied with standard pesticide equipment (Shapiro-llan et al. 2006). According to this information and the literature data obtained, a list containing the entomopathogenic nematodes of $E$. kuehniella and agents for its natural control is given in Table 5.

Ramos-Rodri'guez et al. (2006) investigated the pathogenic effects of some species of the genus Steinernema against stored pests. Entomopathogenic nematodes Steinernema riobrave (Rhabditida: Steinernematidae), S. carpocapsae (Weiser) (Nematoda: Steinernematidae) and S. feltiae (Filipema) (Nematoda: Steinernematidae)) were tested against different pest. As a result of the tests, it was found that $S$. riobrave has the best pathogenicity against $E$. kuehniella. According to the results of the study, they reported that if tested more $S$. riobrave, the would be more reliable.

Athanassiou et al. (2008) tested the mortality effect of different strains of Steinernema feltiae against $E$. kuehniella larvae. Researchers have implemented $S$. feltiae doses against E. kuehniella larvae in different doses. As a result of the study, it was determined $S$. feltiae doses cause mortality between $52 \%$ and $100 \%$. Therefore, the researchers stated that $S$. feltiae could be a promising biological control agent against E. kuehniella.

Athanassiou et al. (2010) tested Heterorhabditis bacteriophora Poinar (Nematoda: Heterorhabditidae), S. carpocapsae and S. feltiae against E. kuehniella larvae. They implemented these nematodes to $E$. kuehniella larvae in different doses. S. feltiae showed a mortality rates between $36.7 \%$ and $78.3 \%$ on E. kuehniella larvae. No death was observed in S. carpocapsae application. In the application of $H$. bacteriophora, very little mortality was observed. As a result of the study, it was determined the effectiveness levels of entomopathogenic nematodes increased depending on the dose. 
Barbosa Negrisoli et al. (2013) tested some entomopathogenic nematodes from the families Steinernematidae and Heterorhabditidae against $E$. kuehniella. They found that most species and/or strains of entomopathogenic nematodes are hypersensitive to $E$. kuehniella. According to the researchers, entomopathogenic nematodes are shown as potential control agents for stored product pests.
Basheer et al. (2014) investigated the potential use of some entomopathogenic nematode isolates against $E$. kuehniella larvae. In this study, four nematode isolates were used. These isolates include Heterorhabditis sp. and Steinernema sp. species. Study results showed that $E$. kuehniella is very sensitive to nematode infections.

Table 5. Entomopathogenic nematodes found or tested for E. kuehniella.

\begin{tabular}{ccc}
\hline Entomopathogen Group & Entomopathogen Species & References \\
\hline & Steinernema sp. & Barbosa Negrisoli et al. (2013), Basheer et al. (2014) \\
Heterorhabditis sp. & Barbosa Negrisoli et al. (2013), Basheer et al. (2014) \\
Steinernema feltiae & Ramos-Rodríguez et al. (2006), Athanassiou et al. (2008) \\
& Steinernema carpocapsae & Ramos-Rodri'guez et al. (2006), Athanassiou et al. (2010) \\
& Steinernema riobrave & Ramos-Rodri'guez et al. (2006) \\
& Heterorhabditis bacteriophora & Athanassiou et al. (2010)
\end{tabular}

\section{CONCLUSION}

The Mediterranean flour moth, Ephestia kuehniella (Zeller) (Lep., Pyralidae) is a major economic insect pest of stored products and cereals. Stored agricultural products and foods have an important place in nutrition and economy. The protection of these products is very important for manufacturers, consumers and exporters. Nevertheless, chemical methods have been used to protect these products. Chemical methods applied to both environmental and human health. There are serious adverse effects on. Therefore, biological control or microbial control are a good alternative to chemical control as it does not harm living organisms other than the target organism and is sensitive to the environment. For this purpose, microbial insecticides have significant potential to control insect pests. Many baculovirus origin products produced for this purpose and commercially available are introduced to the market (Clem and Passarelli 2013). In addition, today, there are many commercial preparations containing entomopathogenic fungi and the preparations are used in the fight against Lepidopteran pests (Goettel et al. 2005). Some species such as Beauveria bassiana, Metarhizium anisopliae and Isaria fumosorosea (= Paecilomyces fumosoroseus) are the most common commercially used in many countries to combat many pests (Rath 2000). Many commercial products and preparations containing $M$. anisopliae are already on the market or are under development (de Faria and Wraight 2007). Although there are many commercial preparations, they are not very useful in the control of storage pests since the storage conditions of fungi are not compatible with the applicable climatic conditions (Doberski 1981). Also, B. thuringiensis and $B$. thuringiensis subsp. kurstaki are bacteria containing commercial preparations that are widely used against Lepidopteran. In addition, entomopathogenic nematodes (genera Steinernema and Heterorhabditis) are effective biological control agents used to control E. kuehniella (Shapiro-llan et al. 2002, 2009). Among the entomopathogens, Bacillus thuringiensis var. kurstaki and baculovirus specific to the pest seem to be most popular against $E$. kuehniella larvae. There is a new interest in using enthomopathogens for biological control of $E$. kuehniella as well as other stored product pests. Detection of different natural pathogens and parasites of E. kuehniella and controlling the population will be most successful in combating with the pest. In this paper, a review of entomopathogenic organisms infecting $E$. kuehniella is presented to stimulate scientist to find possible biological control strategies to control $E$. kuehniella populations.

\section{REFERENCES}

Abdalla MM El-Adawy's, Sayed A, Hany AS Abd El-Gawad (2012) Anagasta kuehniella as an Isolation Bait of Entomopathogenic Agents. Egyp. J. Agric. Res. 90(2): 601-606.

Andreadis TG (1985) Experimental transmission of a microsporidian pathogen from mosquitoes to an alternate copepod host. Proceedings of the National Academy of Sciences 82: 5574-5577.

Arıkan TK, Turan SL (2020) Organochlorine pesticide residues in feathers of four bird species from western part of Turkey. Turk J. Zool. 44: 401-407

Athanassiou CG, Palyvos NV, Kakouli-Duarte T (2008) Insecticidal effect of Steinernema feltiae (Filipjev) (Nematoda: Steinernematidae) against Tribolium confusum du Val (Coleoptera: Tenebrionidae) and Ephestia kuehniella (Zeller) 
(Lepidoptera: Pyralidae) in stored wheat. J. Stored Prod. Res. 44: 52-57.

Athanassiou CG, Kavallieratos NG, Menti H, Karanastasi E (2010) Mortality of Four Stored Product Pests in Stored Wheat When Exposed to Doses of Three Entomopathogenic Nematodes. J. Econ. Entomol. 103(3): 977-984.

Athanassiou CG, Kavallieratos NG, Rumbos Cl, Kontodimas DC (2017) Influence of Temperature and Relative Humidity on the Insecticidal Efficacy of Metarhizium anisopliae against Larvae of Ephestia kuehniella (Lepidoptera: Pyralidae) on Wheat. J. Insect Sci. 17(1): 22, 1-7.

Barbosa Negrisoli CRC, Negrisoli Júnior AS, Bernardi D, Silveira Garcia $M$ (2013) Activity of eight strains of entomopathogenic nematodes (Rhabditida: Steinernematidae, Heterorhabditidae) against five stored product pests. Exp. Parasitol. 134: 384-388.

Basheer AM, Jawish AA, Al-Assas K (2014) Laboratory rearing of entomopathogenic nematodes on Mediterranean flour moth Ephestia kuehniella Zell. Arab. J. Plant Prot. 32(3): 226-233.

BenFarhat D, Dammak M, Khedher SB, Mahfoudh S, Kammoun S, Tounsi S (2013) Response of larval Ephestia kuehniella (Lepidoptera: Pyralidae) to individual Bacillus thuringiensis kurstaki toxins mixed with Xenorhabdus nematophila. J. Invertebr. Pathol. 114(1): 71-75.

Cox P, Wakefield M, Price N, Wildey K, Moore D, Muro MA de, Bell B (2002) Entomopathogenic fungi for the control of invertebrate pests in storage structures. In: Advances in stored product protection. Proceedings of the 8th International Working Conference on Stored Product Protection, York UK, pp 87-94.

Dales MJ (1994). Controlling insect pests of stored products using insect growth regulators and insecticides of microbial origin NRI Bulletin 64. University of Greenwich, Natural Resorces Institute, ISBN: 0-85954-386-2.

de Faria MR, Wraight SP (2007) Mycoinsecticides and mycoacaricides: a comprehensive list with worldwide coverage and international classification of formulation types. Biol. Control 43: 237-256.

Didier ES (2005) Microsporidiosis: An emerging and opportunistic infection in humans and animals. Acta Trop. 94(1): 61-76.

Doberski JW (1981) Comparative laboratory studies on three fungal pathogens of the elm bark beetle, Scolytus scolytus: effects of temperature and humidity on infection by Beauveria bassiana, Metarhizim anisopliae, and Paecilomyces farinosus. J. Invertebr. Pathol. 37: 195-200.

Erakay S (1974) Ege Bölgesinde Un ve Undan Mamül Maddelerde Bulunan Zararli Böcekler Üzerinde Arastirmalar. Istiklal Matbaası, İzmir Teknik bülten, 23: 34-35.

Erkılıç L, Uygun N (1993) Entomopatojen fungusların biyolojik mücadelede kullanılma olanakları. Turk Entomol Derg. 17(2): 117128.

Faraji S, Mehrvar A, Shadmehri AD (2013) Studies on the virulence of different isolates of Beauveria bassiana (Balsamo) Vuillemin and Metarhizium anisopliae (Metcsn.) Sorokin against Mediterranean flour moth, Ephestia kuehniella Zeller (Lepidoptera: Pyralidae). Afr. J. Agric. Res. 8(30): 4157-4161.

Freitas ACO, Gigliolli AAS, Caleffe RTC, Conte H (2020) Insecticidal effect of diatomaceous earth and dolomite powder against Corn weevil Sitophilus zeamais Motschulsky, 1855 (Coleoptera: Curculionidae. Turk J. Zool. 44: 490-497

Ghribi D, Elleuch M, Abdelkefi L, Ellouze-Chaabouni S (2012) Evaluation of larvicidal potency of Bacillus subtilis SPB1 biosurfactant against Ephestia kuehniella (Lepidoptera: Pyralidae) larvae and influence of abiotic factors on its insecticidal activity. J. Stored Prod. Res. 48: 68-72.
Goettel MS, Eilenberg J, Glare T (2005). Entomopathogenic Fungi and Their Role in Regulation of Insect Populations. In: Comprehensive Molecular Insect Science. Gilbert LI, latrou K, Gill SS (eds) Elseiver, Amsterdam, pp 361-405.

Hails RS (2001) Natural and genetically modified baculoviruses: environmentally friendly pest control or an ecological threat? Outlook Agriculture 30: 171-178.

Jallouli W, Abdelkefi-Mesrati L, Tounsi S, Jaoua S, Zouari N (2013) Potential of Photorhabdus temperata K122 bioinsecticide in protecting wheat flour against Ephestia kuehniella. J. Stored Prod. Res. 53: 61-66.

Jamoussi K, Sellami S, Abdelkefi-Mesrati L, Givaudan A, Jaoua S (2009) Heterologous Expression of Bacillus thuringiensis Vegetative Insecticidal Protein-Encoding Gene vip3LB in Photorhabdus temperata Strain K122 and Oral Toxicity against the Lepidoptera Ephestia kuehniella and Spodoptera littoralis. Mol. Biotechnol. 43: 97-103.

Jarrahi A, Safavi SA (2016) Temperature-dependent functional response and host preference of Habrobracon hebetor between fungus-infected and uninfected Ephestia kuehniella larvae. J. Stored Prod. Res. 67: 41-48.

Jurat-Fuentes J, Jackson TA (2012). Bacterial Entomopathogens. In: Insect pathology, Vega, F., Kaya, H. (Eds.). Elsevier.

Karabörklü S, Azizoğlu U, Azizoğlu ZB (2018) Recombinant entomopathogenic agents: a review of biotechnological approaches to pest insect control. World J. Microbiol. Biotechnol. 34: 14.

Krieg A, Huger AM, Langenbruch GA, Schnetter W (1983) Bacillus thuringiensis var. tenebrionis: ein neuer gegenuber arven von Coleopteren wirksamer athotyp. Zeitschrift für Angew. Entomol. 96: 500-508.

Lipa JJ, Triggiani O (1992) A newly recorded neogregarine (Protozoa, Apicomplexa), parasite in honey bees (Apis mellifera) and bumble bees (Bombus spp). Apidologie 23: 533-536.

Lord JC (2003) Mattesia oryzaephili (Neogregarinorida: Lipotrophidae), a Pathogen of Stored-Grain Insects: Virulence, Host Range and Comparison with Mattesia dispora. Biocontrol Sci. Technol. 13(6): 589-598.

Lynn DE, Ferkovich SM (2004) New cell lines from Ephestia kuehniella: characterization and susceptibility to baculoviruses. J. Insect Sci. 4(9): 5.

Mahbubur Rahman M, Roberts HLS, Schmidt O (2007) Tolerance to Bacillus thuringiensis endotoxin in immune-suppressed larvae of the flour moth Ephestia kuehniella. J. Invertebr. Pathol. 96(2): 125-132.

Mahmoud Sabbour M, El-Sayed Abd-El-Aziz S, Adel Sherief M (2012) Efficacy of Three Entomopathogenic Fungi Alone or in Combination With Diatomaceous Earth Modifications for the Control of Three Pyralid Moths in Stored Grains. J. Plant Prot. Res. 52(3): 359- 363

Michalaki MP, Athanassiou CG, Steenberg T, Buchelos CTh (2007) Effect of Paecilomyces fumosoroseus (Wise) Brown and Smith (Ascomycota: Hypocreales) alone or in combination with diatomaceous earth against Tribolium confusum Jacquelin du Val (Coleoptera: Tenebrionidae) and Ephestia kuehniella Zeller (Lepidoptera: Pyralidae). Biol. Control. 40: 280-286.

Mostafa AM, Fields PG, Holliday NJ (2005). Effect of temperature and relative humidity on the cellular defense response of Ephestia kuehniella larvae fed Bacillus thuringiensis. J. Invertebr. Pathol. 90(2): 79-84.

Paula Pereira A, Otília Carvalho M, Rodrigues J, Mexia A (2002) Survey and estimate of moth population density in a flour mill in Cape 
Verde Islands. Integrated Protection of Stored Products, IOBC Bulletin 25(3): 53-63.

Rahimi V, Zibaee A, Mojahed S, Maddahi K, Zare D (2013) Effects of Pyriproxyfen and Hexaflumuron on Cellular Immunity of Ephestia kuehniella Zeller (Lepidoptera: Pyralidae). Rom. J. Bıol. -Zool. 58(2): 151-162.

Ramos-Rodri'guez A, Campbell JF, Ramaswamy SB (2006) Pathogenicity of three species of entomopathogenic nematodes to some major stored-product insect pests. . J. Stored Prod. Res. 42: 241-252.

Rath AC (2000) The use of entomopathogenic fungi for control of termites. Biocontrol Sci Technol. 10: 563- 581.

Sabbour MM (2013) Novel Determinations of Nano-extracted Destruxin from Metarhizium anisopliae against Ephestia cautella and Ephestia Kuehniella (LepidopteraPyralidae) under Laboratory and Store Conditions. Int. J. Sci. Res. ISSN (Online), pp 2319-7064.

Sevim A, Sevim E, Demirbağ Z (2015) Entomopatojenik funguslarin genel biyolojileri ve Türkiye'de zararli böceklerin mücadelesinde kullanilma potansiyelleri. Erzincan Üniversitesi Fen Bilimleri Enstitüsü Dergisi 8(1): 115-147.

Seyedtalebi FS, Safavi SA, Talaei-Hassanloui R, Bandani AR (2017) Quantitative comparison for some immune responses among Eurygaster integriceps, Ephestia kuehniella and Zophobas morio against the entomopathogenic fungus Beuveria bassiana. Invertebr. Surviv. J. 14: 174-181.

Shakarami J, Eftekharifar R, Latifian M, Jafari S (2015) Insecticidal activity and synergistic effect of Beuveria bassiana (Bals.) Vuill. and three botanical compounds against third instar larvae of Ephestia kuehniella. Res. Crop. 16(2): 303.

Shapiro-llan DI, Gouge DH, Koppenhöfer AM (2002) Factors Affecting Commercial Success: Case Studies in Cotton, Turf, and Citrus. In: Entomopathogenic Nematology. Gaugler, R. (Ed.), CABI Publishing, New York, 333-356.

Shapiro-llan DI, Gough DH, Piggott SJ, Patterson Fife J (2006) Application technology and environmental considerations for use of entomopathogenic nematodes in biological control. Biol. Control. 38: 124-133.

Shapiro-Ilan DI, Mbata GN, Nguyen KB, Peat SM, Blackburn D, Adams BJ (2009) Characterization of biocontrol traits in the entomopathogenic nematode Heterorhabditis georgiana (Kesha strain), and phylogenetic analysis of the nematode's symbiotic bacteria. Biol. Control. 51(3): 377-387.

Stejskal V; Stara J, Pekar S, Nesvorna M, Hubert J (2020) Sensitivity of polyphagous (Plodia interpunctella) and stenophagous (Ephestia kuehniella) storage moths to residual insecticides: Effect of formulation and larval age. Insect Sci, 1-11.
Talebi Kh, Hosseininaveh V, Ghadamyari M (2011) Ecological impacts of pesticides in agricultural ecosystem. In: Pesticides in the Modern World-risks and Benefits. In Tech Open Access Publisher, Rijeka, Croatia, 560.

Tulek A, Erturk S, Kepenekçi I, Atay T (2015) Efficacy of Native Entomopathogenic Nematodes against the Stored Grain Insect Pest, Rhyzopertha dominica (F.) (Coleoptera: Bostrichidae) Adults. Egypt J. Biol. Pest Control. 25(1): 251-254.

Valigurová A, Koudela B (2005) Fine structure of trophozoites of the gregarine Leidyana ephestiae (Apicomplexa: Eugregarinida) parasitic in Ephestia kuehniella larvae (Lepidoptera). Eur. J. Protistol. 41(3): 209-218.

Valigurová A, Koudela B (2006) Ultrastructural study of developmental stages of Mattesia dispora (Neogregarinorida: Lipotrophidae), a parasite of the flour moth Ephestia kuehniella (Lepidoptera). Eur. J. Protistol. 42(4): 313-323.

Vega FE, Meyling NV, Luangsa-ard JJ, Blackwell M (2012) Fungal Entomopathogens. In: Insect pathology. Vega, F., Kaya, H. (Eds.). Elsevier.

Weiser J, Purrini K (1985) Light- and electron-microscopic studies on the microsporidian Vairimorpha ephestiae (Mattes) (Protozoa, Microsporidia) in the meal moth Ephestia kuhniella. Arch. Protistenkd. 130(3): 179-189.

Wildey KB, Cox PD, Wakefield M, Price NR, Moore R, Bell BA (2002) The use of entomopathogenic fungi for stored product pest control The "MYCOPEST" Project. Integrated Protection of Stored Products, IOBC Bulletin 25(3): 15-19.

Wouts WM (1991) Steinernema (Neoaplectana) and Heterorhabditis species. In: Manual of Agricultural Nematology. Nickle, W. R. and Dekker, M. (Eds.), 1016-1035.

Yaman M, Radek R, Weiser, Aydın Ç (2010) A microsporidian pathogen of the predatory beetle Rhizophagus grandis (Coleoptera: Rhizophagidae). Folia Parasitol. 57: 233-236.

Yaman M, Acar KF, Radek R (2015) A Nucleopolyhedrovirus from the Mediterranean flour moth, Ephestia kuehniella (Lepidoptera: Pyralidae). Appl. Entomol. Zool. 50(3): 355-359.

Yaman M, Acar KB, Radek R (2019) First record of the entomopathogenic protist, Mattesia dispora (Neogregarinorida: Lipotrophidae) of the Mediterranean flour moth, Ephestia kuehniella Zeller (Lepidoptera: Pyralidae) in Turkey. Egypt J. Biol. Pest Control. 29: 78.

Yaman M, Algı G, Radek R (2019) Morphological, ultrastructural and molecular identification of a new microsporidian pathogen isolated from Crepidodera aurata (Coleoptera, Chrysomelidae). Turk J Zool. 43: 407-415. 